\title{
Prototype Geographic Information Systems Mapping of Crop Products Featured Local
}

\author{
Teddy Oswari, Euphrasia Susy Suhendra, Emy Haryatmi, Fenni Agustina \\ Gunadarma University, Jakarta, Indonesia \\ Email: toswari@staff.gunadarma.ac.id, susys@staff.gunadarma.ac.id,emy_h@staff.gunadarma.ac.id, \\ fenny@staff.gunadarma.ac.id
}

Received October 11, 2012; revised January 10, 2013; accepted March 10, 2013

Copyright (C) 2013 Teddy Oswari et al. This is an open access article distributed under the Creative Commons Attribution License, which permits unrestricted use, distribution, and reproduction in any medium, provided the original work is properly cited.

\begin{abstract}
Local featured program in Indonesia cannot be separated entirely from commodity strategic bases. Until in 2006, agricultural development formulation showed indicative targets for featured crops commodity production. The problem of food security is forming of farmer's independence to protect local resources in efficiently and optimally, so these resources can be more utilized. It can be achieved by assist of information technologies and communication in forming of Geographic Information System (GIS) to support consistency of food security in Indonesia. This research designs prototype geographic information system in order to conduct the accurate mapping and to know the local featured crops production in Indonesia. This level is conducted for documentation and mapping of agricultural products which is the local featured production. This documentation requires the usage of potential physical, economic, social and cultural environment by the utilization of information technology and communication, which have the ability of relevancy and accessibility of reliable information.
\end{abstract}

Keywords: Geographic Information System; Mapping; Local Seed Plants

\section{Introduction}

Local featured program in Indonesia cannot be separated entirely from commodity strategic bases. It is stated from the agricultural development formulation show indicative targets for featured crops commodity production until in 2006. However, the decrease in cultivated area per farmer and limited supply of irrigation water and high input prices and relatively low price of products can be the limited factors and obstacles for welfare programs and independence farmers based on the local resources.

Efforts towards improving the welfare of farmers will be conducted by empowerment counseling, mentoring, business assurance, price protection, and promotion policies. These efforts are relatively needed, meanwhile the constraints factor should need more attention to the local level.

Grand strategy from Department of Agriculture is development of agribusiness which basically includes 4 important things, namely: 1) Agricultural development must be the priority of national development. 2) Agricultural development must be conducted through agribusiness system. 3) The success of the agribusiness development depends on the factors and policies that are beyond the jurisdiction of the Department of Agriculture so it is needed the excellent coordination efforts among agencies. 4) Development of agribusiness should be able to improve competitiveness, build economy, sustainable and decentralized within the framework of strengthening the local economy, so agribusiness development is conducted by patterns of development potential and capacity of the local economy

Researchers [1], explained and applied Geographic Information System is needed to adjust production balancing of horticultural crops in West Java and useful to get accurate information about the composition of vegetable supply needs for commodity tomatoes, potatoes and red peppers in Bandung regency. Now, this research and application of Geographic Information Systems in local commodities in Indonesia should be the basis of data on all commodities for farmers and businesses in order to increase competitiveness and value of export sales to many countries.

Researcher [2] said in his research, in fact the food security program cannot be separated from the development of food security to fill the food needs of community in sufficient, nutritious, safe, taste quality and belief, 
through increased productivity, quality, and efficiency of production plant origin food and food diversification.

The problem of food security is forming of farmer's independence to protect local resources in efficiently and optimally, so these resources can be more utilized. It can be achieved by assist of information technologies and communication in forming of Geographic Information System to support consistency of food security in Indonesia.

Researcher [3], explanation efforts towards improving the welfare of farmers will be conducted by empowerment counseling, mentoring, business assurance, price protection, and promotion policies. These efforts are relatively needed meanwhile the constraints factor should need more attention to the local level. The farmers in Indonesia can understand the food commodities which classified in terms of subsistence farmers as producers as well as consumers.

Related to this explanation above, the factor which should be conducted is documentation and mapping of agricultural products which is local featured production. This documentation requires the usage of potential physical, economic, social and cultural environment. One of the potential that can be used for documentation and mapping of agricultural products in Indonesia is the utilization of information and communication technology. The use of information technology and computer in the preservation of national culture is conducted by the development of local resources documentation in the field of agriculture which support the food security program with the current available of data with high complexity, and ability of relevancy and accessibility of reliable information [4].

The purpose of this research is formed of documentation, determination of local resources and formed of Geographic Information System to support the improving agricultural production through the design of prototype Geo- graphic Information System for mapping product of local featured product.

The target plan of crops documentation and forming Geographic Information System is every province on the island of Java, Sumatera and Kalimantan can improve agricultural production, incomes of farmers, quality of agricultural products and agro-industry, and forming of agricultural organizations and institutions also improving of food self-sufficiency.

\section{Research Method}

This research consists of four steps: 1) Collecting data of crops production in selected provinces in Indonesia; 2) Designing database and crops taxonomy; 3) Mapping of crops in each district on the island of Java; 4) Designing of creation portal digital crops plan with variety of features such as database of crop productivity, crop taxonomy, e-book, CAL, Spatial Database with Geographic
Information System for special area of crops and Virtual Reality.

The usage of this research includes: 1) Database which is produced about food crops and taxonomy are expected to know specific of crops in district, so it can reduce dependence on crop products. 2) Database of crops Taxonomy can be reference to crops development in district. 3) Portal virtual crops can fill the needs of each district to develop characteristic of crops in district. 4) Geographic Information System map in portal of virtual crops can be reference for other users to know potential crops of province. 5) Geographic Information System map can invite investors in order to invest their funds for the food crops development.

\section{Results and Discussion}

The designing steps of prototype web digitizing crops based on Geographic Information System to the local featured commodities are: 1) Decide the observation and research area in Java; 2) Determine the spatial and non-spatial data in certain areas, e.g. in Yogyakarta; 3) Conduct the tracking of spatial data; 4) Create Database; 5) Create web and connection.

Story-board Web Geographic Information System designed is began prototype web identification, such as on these charts: 1) Explanation of grant program in designing web and slide show of local featured crops figure; 2) Provide web content information and featured commodities graphics, product in each region; 3) Explanation of Geographic Information System web content; 4) Show e-book in several of local featured with information of product and figure; 5) Show map of products location which have the local featured crops; 6) Provide the information of research team; 7) Completeness of web content.

Design interface website Geographic Information System refers to the book [5-7]. The Figure 1 describes the steps of design interface website.

This research shows Yogyakarta province as the area selected for baseline data collection. These are 5 (five) regions in the Yogyakarta. The following Table 1 explains data of Harvest Coverage, Production and Productivity.

This Table 2 shows the data of each regency, which contains regency code and regency name (e.g. Yogyakarta, K $\underline{02}$ 001: show $\underline{02}$ Yogyakarta, $\underline{01}$ Bantul). As the table below.

This Indicators table shows the data of each indicator, which contain of Code_Indicator, Name indicators, and unit (e.g. I1: shows harvest coverage with Ha (hectare) unit. As the Table 3 below.

This Plant table shows the data of each plant, which contain of Code_Plant, and Name_Plant (e.g. T01: show maize plant, T02: Green Bean plant). As the Table 4 below. 


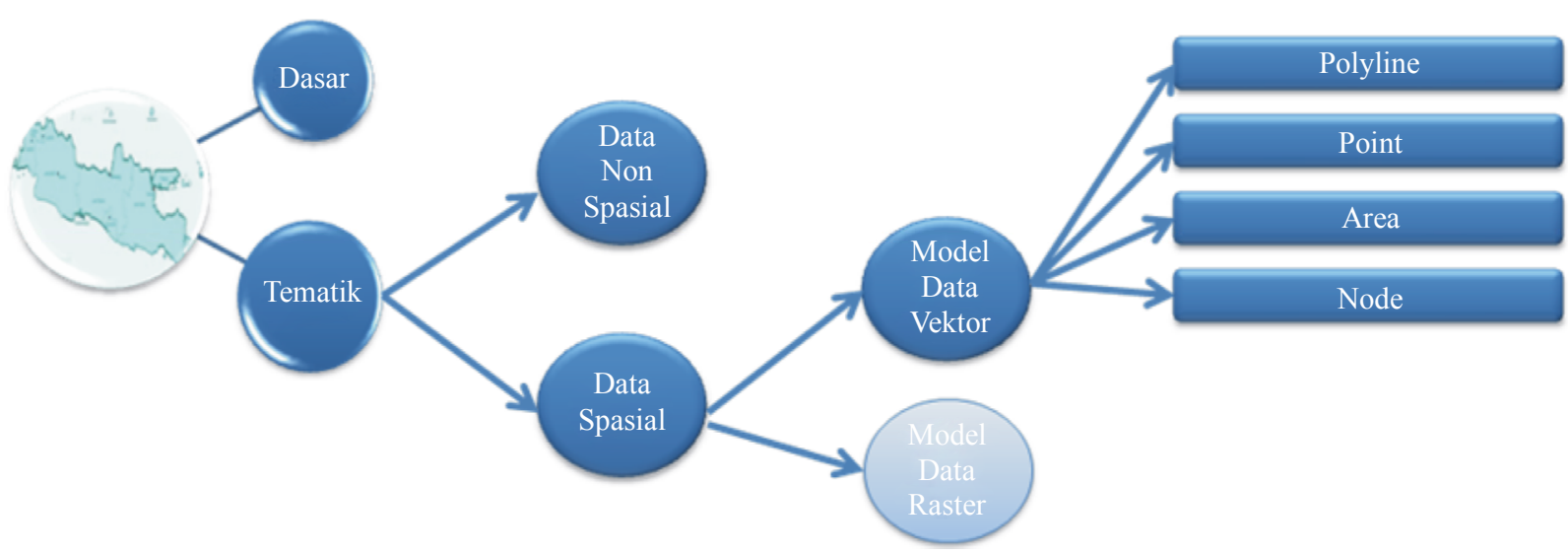

Figure 1. Design of geographic information system.

Table 1. Data of harvest coverage, production and productivity in the province of Yogyakarta.

\begin{tabular}{|c|c|c|c|c|c|}
\hline \multirow{3}{*}{\multicolumn{2}{|c|}{ Regency }} & \multicolumn{4}{|c|}{$\begin{array}{c}\text { Indicator: } \\
\text { Harvest Coverage }\end{array}$} \\
\hline & & \multicolumn{4}{|c|}{ Unit: HA 2008-2010 } \\
\hline & & 08 & $\mathbf{0}$ & & 10 \\
\hline \multicolumn{2}{|c|}{ Kulon Progo } & 5.047 & \multicolumn{2}{|c|}{5.316} & 4.986 \\
\hline \multicolumn{2}{|c|}{ Bantul } & 5.739 & \multicolumn{2}{|c|}{6.290} & 5.523 \\
\hline \multicolumn{2}{|c|}{ Gunung Kidul } & 55.347 & \multicolumn{2}{|c|}{57.528} & 71.223 \\
\hline \multicolumn{2}{|c|}{ Sleman } & 5.029 & \multicolumn{2}{|c|}{5.570} & 5.105 \\
\hline \multicolumn{2}{|c|}{ Yogyakarta } & 2 & \multicolumn{2}{|c|}{1} & \\
\hline \multicolumn{3}{|c|}{ Indicator: Production } & \multicolumn{3}{|c|}{ Indicator: Productivity } \\
\hline \multicolumn{3}{|c|}{ Unit: TON 2008-2010 } & \multicolumn{3}{|c|}{ Unit: $\mathbf{K u} / \mathbf{H A}$} \\
\hline 08 & 09 & 10 & 08 & 09 & 10 \\
\hline 33.279 & 33.169 & 27.891 & 65.94 & 64.11 & 55.94 \\
\hline 30.177 & 28.776 & 29.539 & 52.58 & 45.75 & 53.48 \\
\hline 191.007 & 220.275 & 256.443 & 34.51 & 38.29 & 36.01 \\
\hline 30.896 & 32.712 & 31.703 & 61.44 & 58.73 & 62.1 \\
\hline 13 & 5 & & 64.65 & 49 & \\
\hline
\end{tabular}

Table 2. Code of province of Yogyakarta.

\begin{tabular}{cc}
\hline Regency Code & Regency Name \\
\hline K02001 & Bantul \\
K02002 & Gunung Kidul \\
K02003 & Kulon Progo \\
K02004 & Sleman \\
K02005 & Yogyakarta \\
\hline
\end{tabular}

Table 3. Name of observation indicator.

\begin{tabular}{ccc}
\hline Indicator Code & Indicator Name & Unit \\
\hline I1 & Harvest coverage & HA \\
I2 & Production & TON \\
I3 & Productivity & Ku/HA \\
\hline
\end{tabular}

Table 4. Name of local featured products in DI Yogyakarta.

\begin{tabular}{cc}
\hline Area Code & Plants \\
\hline T01 & Maize \\
T02 & Green Bean \\
T03 & Peanut \\
T04 & Soybean \\
T05 & Rice \\
T06 & Sweet potato \\
T07 & Cassava \\
\hline
\end{tabular}

The main table is relation table between various tables in above. The main table consists of Primary Key of each table, beside that the amount of data inputted based on the year, i.e. 2008, 2009, 2010 (e.g. Yogyakarta and 5 (five) regency, in maize plant with Harvest coverage indicators, we input the data in 2008, 2009, 2010).

On the main web page, there are 7 menus such as Home, Profile, Map, Table, Graphic, E-book, about us. Especially, there is explanation about website in Home page. The following Figure $\mathbf{2}$ is plan of prime display.

On the profile page, there is a detailed explanation about function and ways of working of all content in Web Geographic Information System "Crop Digitizing based Geographic Information System in Local Featured Commodities in Indonesia". The following Figure $\mathbf{3}$ is profile design mapping for all areas. 


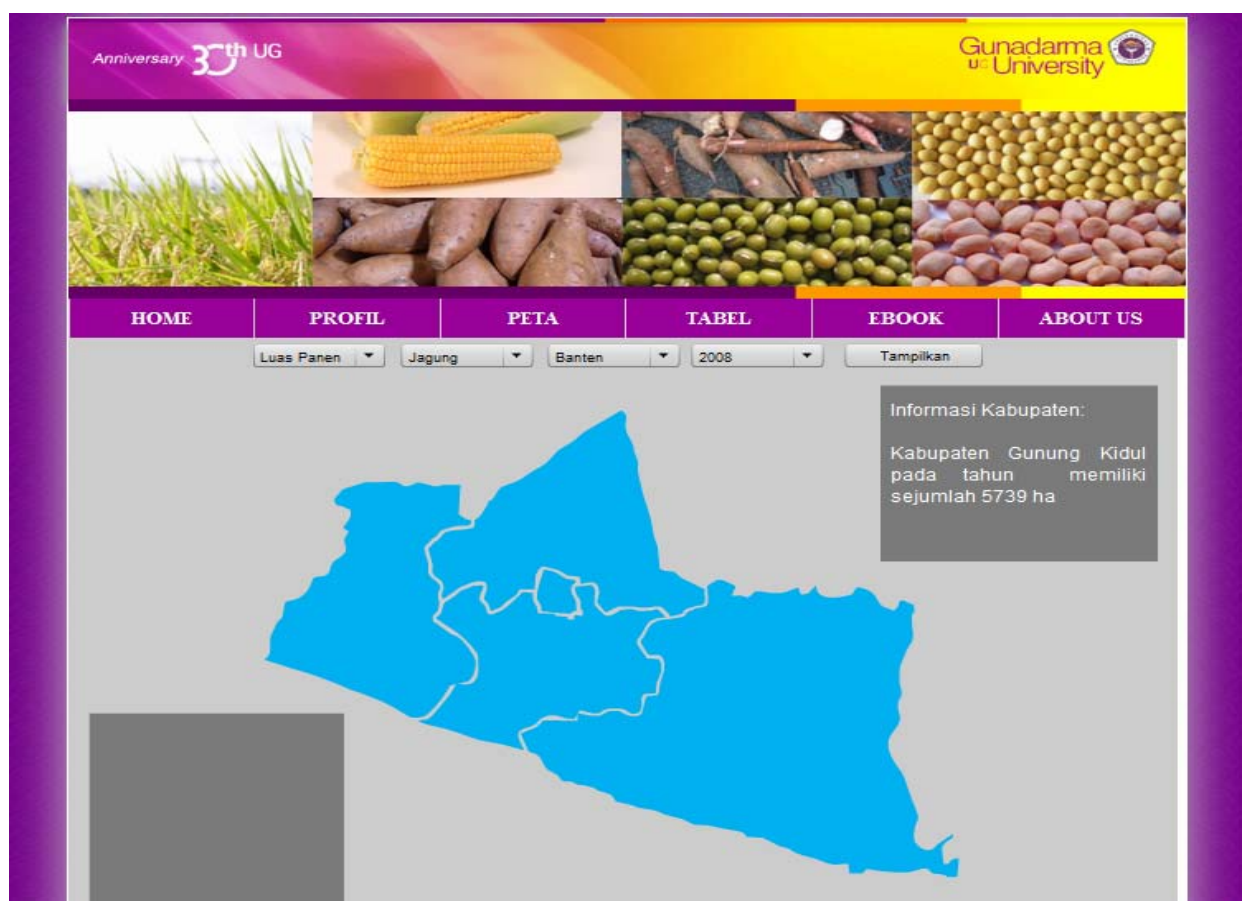

Figure 2. Plan of prime display.

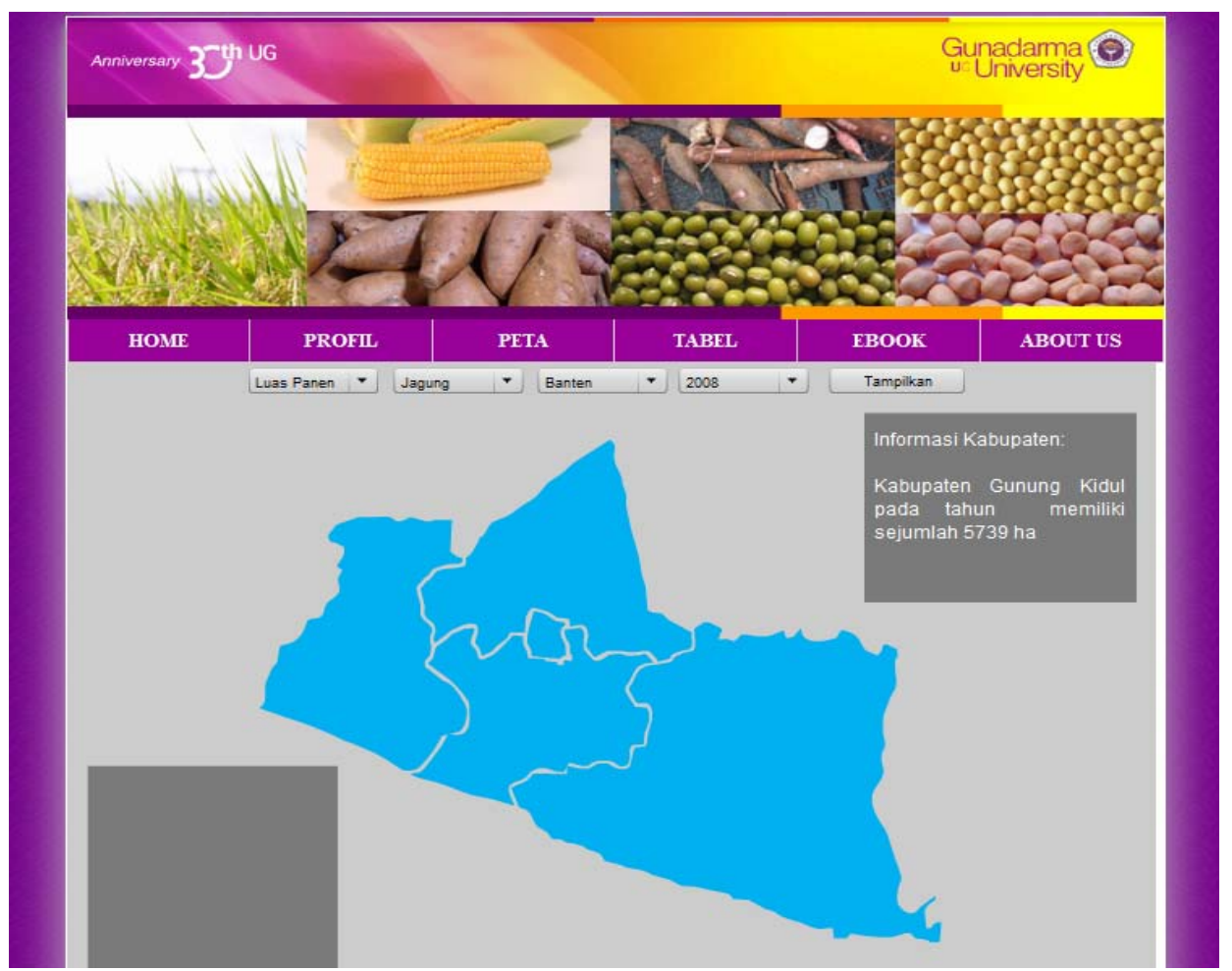

Figure 3. Profile design.

On the map page, there is Default Java Island with 6 Province. Moreover user show data mapping based on chosen of indicator category, Plant, Region, and year. Provided information is data each regency in transparent gray for specific area which automatically works, it is based on diosmose over region and color index as data mapping reference. This is an example of data mapping in Yogyakarta, with harvest coverage indicators, maize plant, Kulonprogo, in 2008. The following Figure 4 describes Yogyakarta Map and Bantul Regency. 


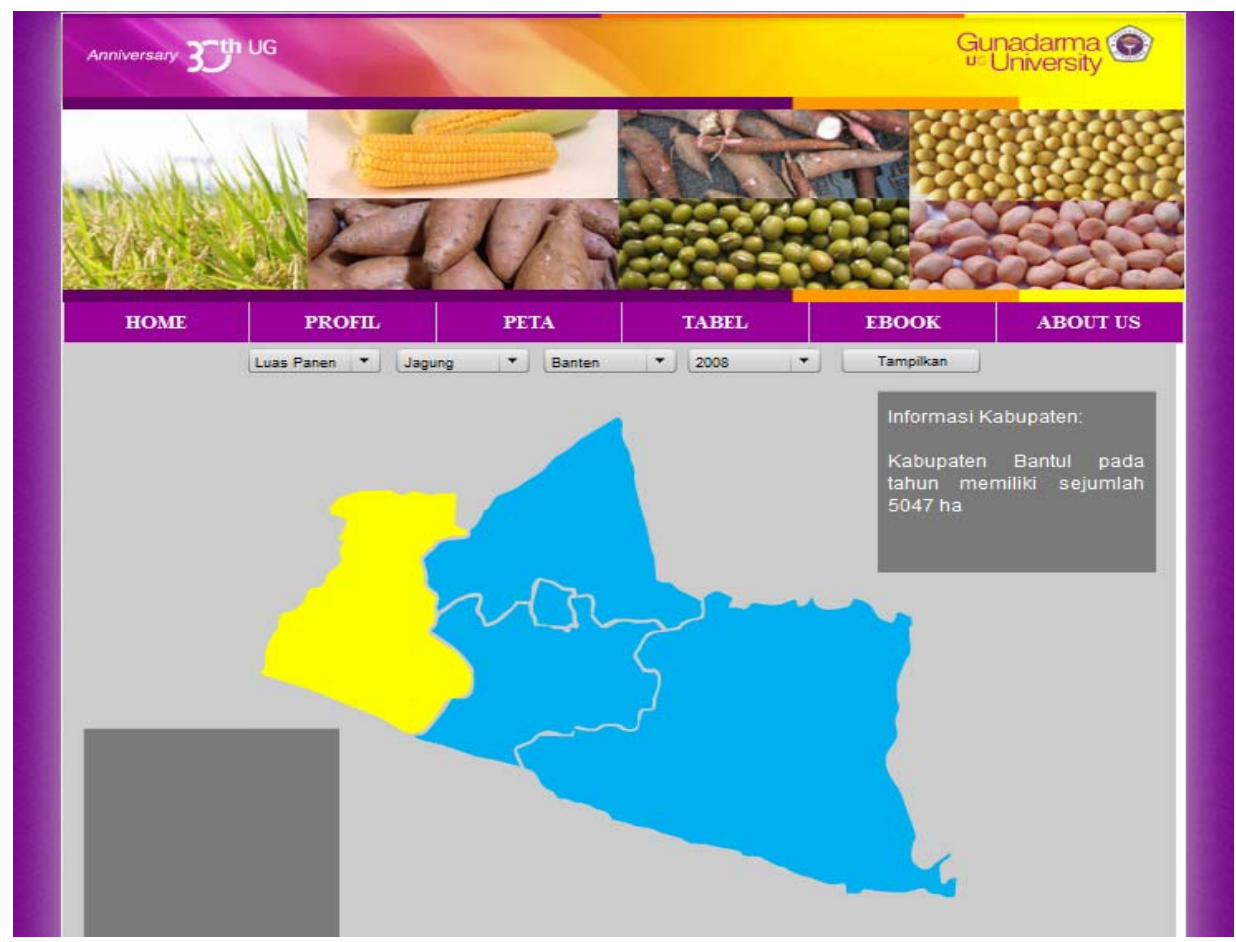

Figure 4. Yogyakarta map, Bantul regency.

This table shows data information of each regency based on chosen of indicator category, plant, area e.g. Yogyakarta, with production indicator, maize plant, in 2008, 2009 and 2010.

\section{Conclusions}

Food security and featured commodities continue to be improved by the government, especially all of the areas which able to dig featured commodities. Moreover improving of farmers' welfare need long and short term policy such as the policy of protection farmers with the import restrictions, but it should be supported by policies to improve local production through improving effort of crop featured productivity such as in Java, Sumatra and Sulawesi.

This research tries to design prototype geographic information system in order to conduct the accurate mapping and to know the local featured crops production in Indonesia. This level is conducted for documentation and mapping of agricultural products which is the local featured production. This documentation requires the usage of potential physical, economic, social and cultural environment by the utilization of information technology and communication, which have the ability of relevancy and accessibility of reliable information.

\section{REFERENCES}

[1] A. Rosita, "Utilization of GIS for E-Agriculture in the
Contect Set to Balance Horticultural Crop Production," Proceedings of National Seminar Information Technology, Indonesian Islamic University, Yogyakarta, 2007.

[2] Z. Duran, A. Garagon Doğru and G. Toz, "Web-Based Multimedia Geographic Information System for Historical Sites," International Symposium CIPA, Antalya, 3-5 November 2003, p. 592.

[3] K. Hosse and M. Schilcher, "Temporal Geographic Information System for Analysis and Visualizations of Cultural Heritage," Institute of Geodesy, Geographic Information System and Land Management, Technical University of Munich, Munich, 2002.

[4] W. Z. Mao, R. A. Dutton, J. Chen and W. Watson, "Parallel Job Scheduling with Overhead: A Benchmark Study," Proceedings of the IEEE International Conference on Networks, Architecture, and Storage (NAS), Chongqing, 12-14 June 2008, pp. 326-333.

[5] E. Prahasta, "Konsep—Konsep Dasar Sistem Informasi Geografis," Informatika Bandung, Bandung, 2005.

[6] E. Prahasta, "Membangun Aplikasi Web-Based Geographic Information System Dengan MapServer," Informatika Bandung, Bandung, 2007.

[7] E. Budiyanto, "Sistem Informasi Geografis Menggunakan ArcView GIS," Penerbit Andi, Yogyakarta, 2002. 